\title{
Correlation of Saalian, Eemian and Weichselian foraminiferal zones in North Jutland
}

\author{
KAREN LUISE KNUDSEN
}

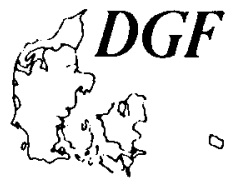

Knudsen, K. L.: Correlation of Saalian, Eemian and Weichselian foraminiferal zones in North Jutland. Bull. geol. Soc. Denmark, vol. 33, pp. 325-339, Copenhagen, February, 28th, 1985.

Foraminifera from 15 boreholes put down through Quaternary deposits in North Jutland have been examined. The biostratigraphy of these borings allows a comparison with the biozones N1-N4 already established at Skærumhede I. The most well defined zone over the whole area is the Eemian zone N3, which contains boreal to boreal -lusitanian deep-water faunas. The lowermost boundary of this zone drops from $155 \mathrm{~m}$ below sea-level in the southwest of the area to about $205 \mathrm{~m}$ in the north, and its thickness normally ranges from 25 to $60 \mathrm{~m}$. Variations in the depth and thickness of zone N3 may suggest that tectonic movements have been active in the area during the Late Quaternary.

In the southern part of the region an arctic zone N4 was observed underlying the Eemian. Marine conditions must therefore have inundated the areas at the end of the preceding glacial period - the Saalian. The upper two biozones, $\mathrm{N} 2$ and $\mathrm{N} 1$, foretell of the onset and development of arctic climatic conditions and are referred to the Early and Middle Weichselian.

K. L. Knudsen, Department of Micropaleontology, Institute of Geology, University of Aarhus, 8000 Arhus C, Denmark. August, 30th, 1984.

The Frederikshavn area (fig. 1) has been the subject of several geological investigations since Jessen et al. (1910) first reported a thick sequence of essentially marine deposits through the Quaternary (see Bahnson et al., 1974; Knudsen and Lykke-Andersen, 1982; Knudsen, 1984). The marine sequence in this area spans a time interval from Late Saalian to Middle Weichselian. Of particular interest is the presence of up to $60 \mathrm{~m}$ of marine interglacial deposits referred to the Eemian, which attest to the existance of an embayment in North Jutland at that time. The latereal extent of these deposits, both onshore and in the Kattegat, remains to be investigated in detail.

This paper endeavours to fill at least part of the above mentioned gap in our knowledge, by incorporating evidence from a number of gas exploration boreholes, which were put down in the Frederikshavn area between 1941 and 1945. From several hundred boreholes 13 have been selected for detailed analysis. Two additional boreholes were chosen, one put down at Hørby (fig. 2) in 1937 in search of gas, and a second, an oil boring dating from 1951 at Skagen (Skagen 2, fig. 2). The major criteria for borehole selection included depth (190-254 m) and the availability of sufficiant workable material for foraminiferal analyses. All the borelogs and the material that survives is stored by the Danish Geological Survey in Copenhagen. The borehole numbers used here correspond to the Survey's original file numbers.

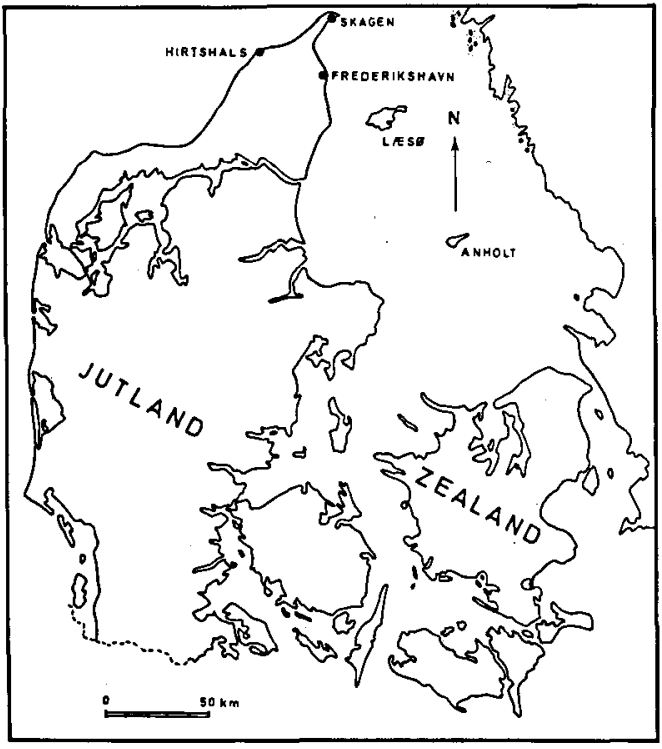

Fig. 1. Location map. 
Table 1. Brief summary of the drilling methods and the condition of available sample material from each of the investigated borings. Detailed descriptions of foraminiferal stratigraphy in the borings Apholm 7.131b, Skærumhede I and Skarumhed II are already published (Knudsen, 1984, Knudsen and Lykke-Andersen, 1982 and Konradi and Knudsen, 1974).

\begin{tabular}{|c|c|c|c|c|}
\hline Locality & $\begin{array}{l}\text { Boring } \\
\text { number }\end{array}$ & & $\begin{array}{l}\text { Boring } \\
\text { made with } \\
\text { outer well } \\
\text { casing }\end{array}$ & $\begin{array}{l}\text { Available sample } \\
\text { material }\end{array}$ \\
\hline Apholm (Publ.) & $7.131 b$ & & + & Undisturbed core samples \\
\hline Elling E. & 7.456 & . & + & Washed fractions $(>0.1 \mathrm{~mm})$ of cuttings \\
\hline Elling W. & 6.29 & & + & Washed fractions ( $>0.1 \mathrm{~mm})$ of cuttings \\
\hline Flade & 7.228 & & + & Raw samples, cuttings \\
\hline Frederikshavn & 7.180 & & + & Raw samples, cuttings \\
\hline Frederikshavn & 7.545 & & to $70 \mathrm{~m}$ & Washed fractions $(>0.1 \mathrm{~mm})$ of cuttings \\
\hline Frederikshavn & 7.555 & & to $38 \mathrm{~m}$ & Washed fractions ( $>0.1 \mathrm{~mm}$ ) of cuttings \\
\hline Frederikshavn & 7.602 & & + & $\begin{array}{l}\text { Washed fractions ( }>0.1 \mathrm{~mm} \text { ) of cuttings. A few undis- } \\
\text { turbed and a few washed core samples }\end{array}$ \\
\hline Hørby & 11.28 & & $+(?)$ & Raw samples, cuttings (very few) \\
\hline Jerup E. & 7.481 & ᄂ & + & Washed fractions $(>0.1 \mathrm{~mm})$ of cuttings \\
\hline Jerup $\mathbf{W}$. & 7.579 & & + & Washed fractions $(>0.1 \mathrm{~mm})$ of cuttings \\
\hline Skagen & 2 & & - & Raw samples, cuttings \\
\hline Skarumhede (Publ.) & $\mathbf{I}$ & & + & Partly raw, partly washed samples, cuttings \\
\hline Skærumhede (Publ.) & II & & + & "Sand pumps" samples, raw material \\
\hline Stenhave & 7.614 & & + & $\begin{array}{l}\text { Washed fractions ( }>0.1 \mathrm{~mm}) \text { of cuttings. A few undis- } \\
\text { turbed core samples }\end{array}$ \\
\hline Strandby Hede & 7.576 & & + & Washed fractions $(>0.1 \mathrm{~mm}$ ) of cuttings \\
\hline Ålbak & 6.30 & & + & Washed fractions ( $>0.1 \mathrm{~mm}$ ) of cuttings \\
\hline
\end{tabular}

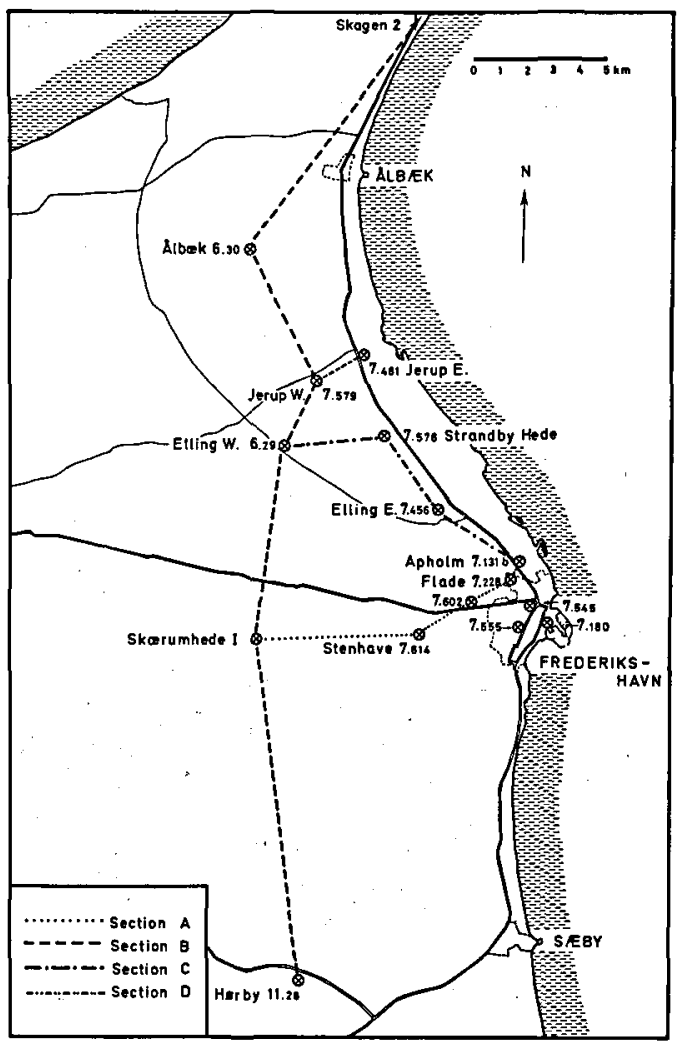

\section{Material and methods}

The condition of the available sample material varies from one boring to another, thus effecting the precision to which stratigraphical interpretations can be made. This information is summerized on Table 1. Most borings were put down using an outer well casing, although in some instances this procedure was not continued throughout the borehole (Table 1). Undisturbed core samples were available from Apholm 7.131 b between 86 and $190 \mathrm{~m}$, and a few cores existed from two other borings. Cutting samples were usually available, but in most cases only washed fractions greater than $0.1 \mathrm{~mm}$ remained. As it is unknown, from which of these samples foraminifera have earlier been picked, the faunas may be incomplete. It has nonetheless, been possible in most cases to identify at least some of the biozones known from the Skærumhede I boring (Knudsen and Lykke-Andersen, 1982).

Fig. 2. Investigated borings in the Frederikshavn area. The borehole numbers are the original file numbers used by the Geological Survey of Denmark, Copenhagen. Cross-correlations between the boreholes along the sections $A, B, C$ and $D$ are illustrated on the diagrams figs. $7,8,9$ and 10 . 


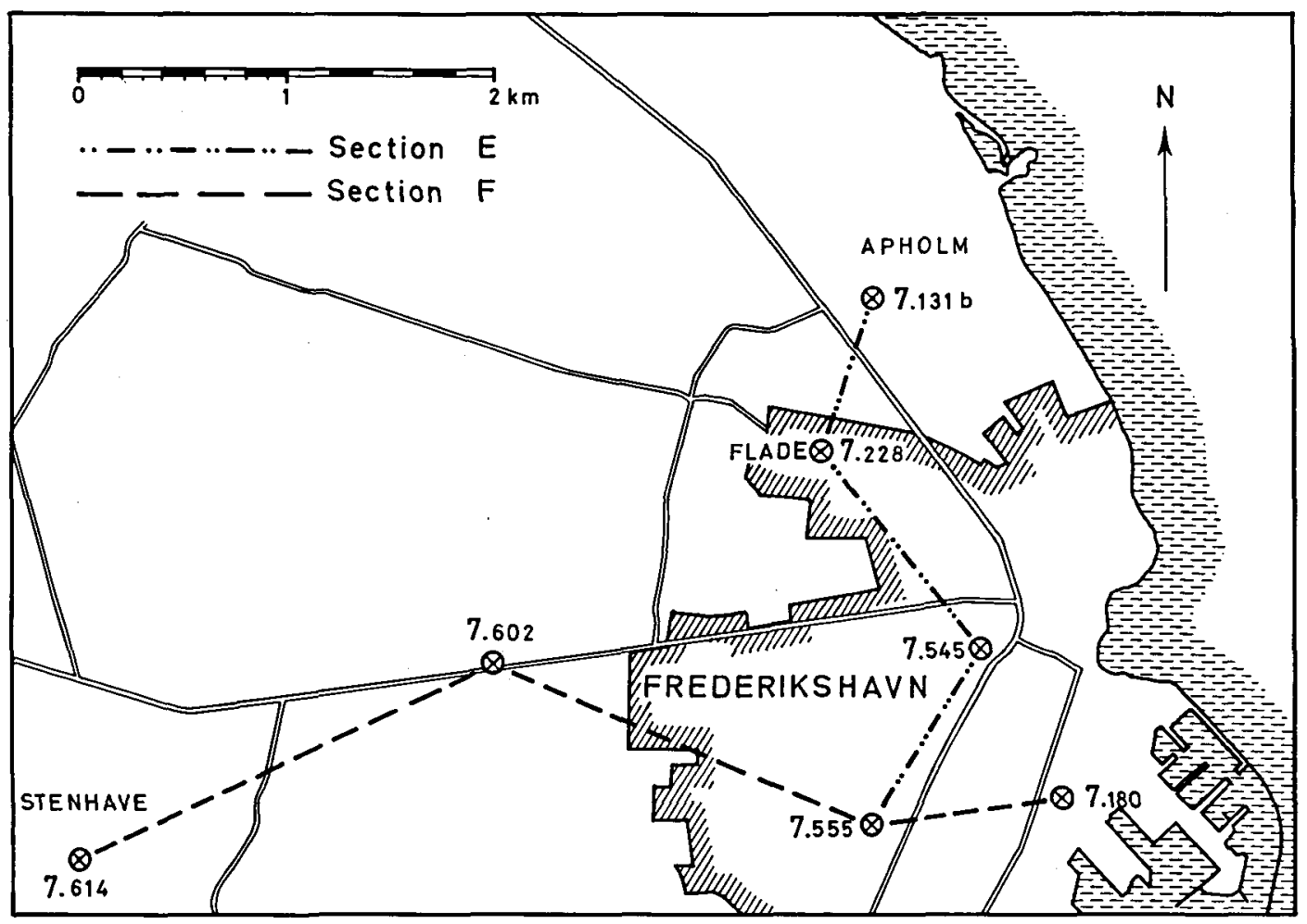

Fig. 3. Locations of borings in Frederikshavn. Cross-correlations between the boreholes along sections $\mathrm{E}$ and $\mathrm{F}$ are illustrated on the diagrams figs. 11 and 12.

Raw samples have been processed according to the methods described by Feyling-Hanssen et al. (1971) and by Meldgaard and Knudsen (1979). Foraminifera in the washed samples were concentrated using a heavy liquid with a specific weight of $1.75 \mathrm{~g} / \mathrm{ccm}$.

The foraminiferal faunas have been quantitatively analysed in three borings (Stenhave 7.614, Frederikshavn 7.602 and Apholm 7.131b). A detailed description of the foraminiferal zonation of the cored Apholm (7.131b) boring is given elsewhere (Knudsen, 1984). The biostratigraphy of the other two boreholes is described in detail below (also see figs. 4 and 6). This results in an impression of the utility and limitations of the material. Stenhave (7.614) represents a boring with a faunal succession, which is typical for the whole area, whereas Frederikshavn (7.602) contains a quite different succession.

The faunas from the rest of the borings were only briefly examined, and the species compositions estimated. As a check a few selected faunas from the borings were also analysed. The zona- tions of these borings are not described separately, but are used when correlating across the whole region.

For practical purposes the same zonation scheme (N1 to N4) as was utilized in the Skærumhede I boring (Knudsen and Lykke-Andersen, 1982) is also used here. The lower and upper boundary of zone N3 were usually well defined, whereas the zone $\mathrm{N} 2 / \mathrm{N} 1$ boundary was indistinct in many borings. This was presumably caused by the original sampling procedure, which tended to obliterate minor faunal changes. Only the more radical faunal changes are clearly defined. When the exact level of a biostratigraphical boundary is uncertain, the correlation is shown with a dashed line instead of a solid line on the diagrams.

\section{Stenhave boring 7.614}

Stenhave is located about $6 \mathrm{~km}$ east of Skarumhede (fig. 2). The borehole site is $50.5 \mathrm{~m}$ above sea-level (a.s.l.), and the boring was $217 \mathrm{~m}$ deep. 
The available material from the Stenhave boring was mainly washed samples $(>0.1 \mathrm{~mm}$ ) from cuttings. Only two undisturbed core samples existed, but they were both from a level just below the marine sequence. The marine sequence from $53 \mathrm{~m}$ to $216.60 \mathrm{~m}$ depth in the borehole was subdivided into three biozones (fig. 4) based on a quantitative analysis of the foraminiferal faunas. The pre-Quaternary content was low in all the investigated samples.

Two core samples from $216.95 \mathrm{~m}$ and $216.75 \mathrm{~m}$ depth contain only very few specimens of foraminifera, and this deposit is therefore considered as non-marine. The sediment is a lightcoloured calcareous stony clay, which was origi- nally interpreted as a till (files in Geological Survey).

Six samples from $216.50 \mathrm{~m}$ to $180 \mathrm{~m}$ depth are included in zone $\mathrm{N3}$. The lowermost sample $(216.50 \mathrm{~m})$ from this interval consists of very sandy clay with pebbles. Above $212.10 \mathrm{~m}$ the sediment is mainly clay and sandy clay, and only the sample at $190 \mathrm{~m}$ contains some coarse sand and pebbles. Boreal and boreal-lusitanian species are usually dominant in zone N3. The zone is characterized by high frequencies of Bulimina marginata, Cassidulina laevigata and Hyalinea balthica together with many other indicators of warm interglacial conditions. The lusitanian species Quinqueloculina padana occurs in most of the

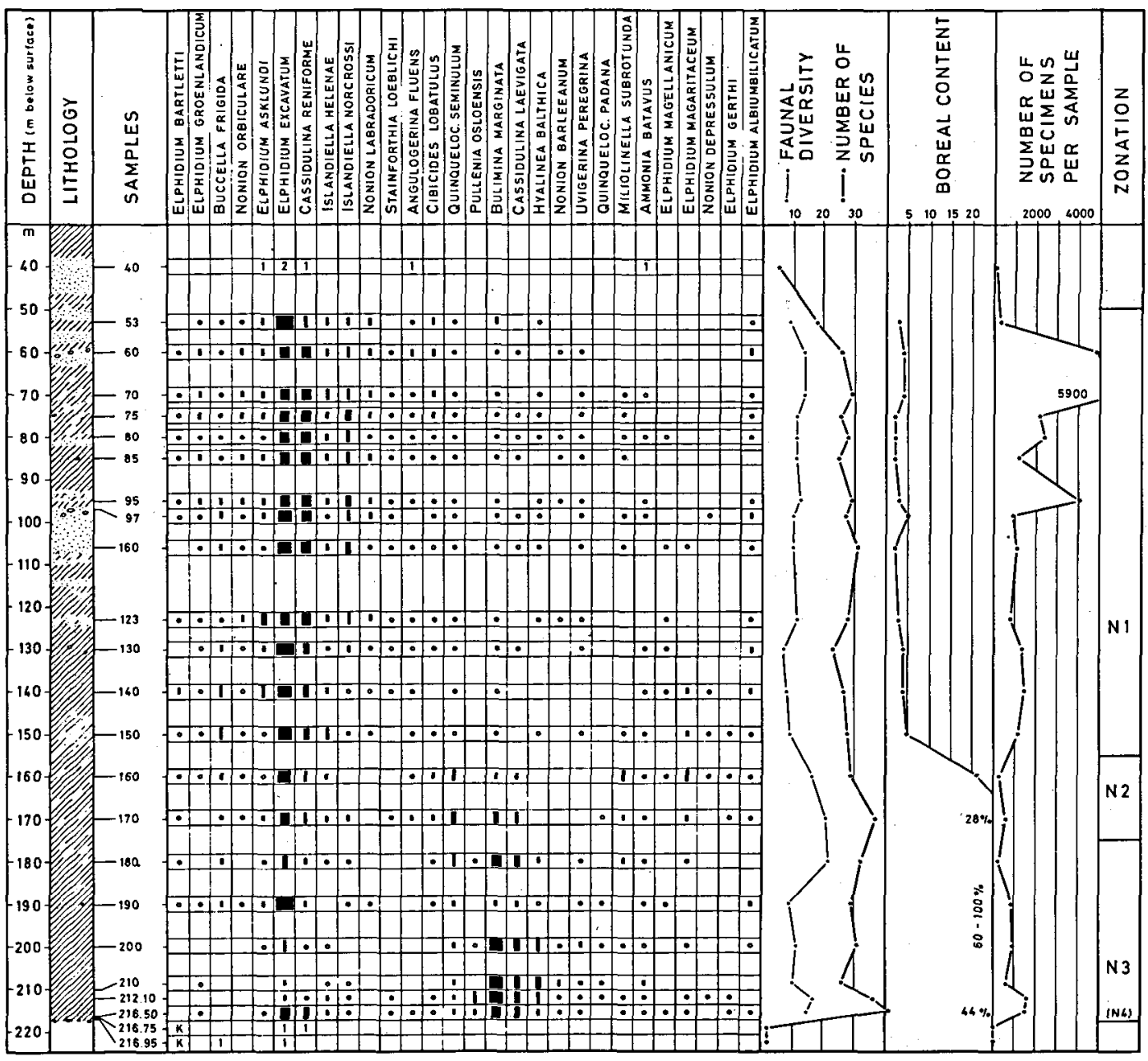

Fig. 4. Percentage distribution of selected foraminiferal species in Stenhave boring 7.614 (legend fig. 5). $\mathrm{K}=$ core sample. Ground level is $50.5 \mathrm{~m}$ above sea-level. 


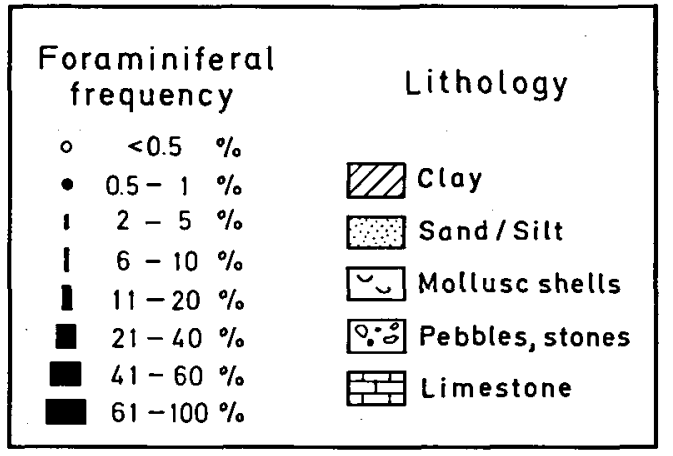

Fig. 5. Legend for the range charts, figs. 4 and 6 , and for lithology in the cross-sections, figs. 7, 8, 9, 10, 11 and 12 .

samples. The zone N3-faunas indicate a water depth of about $60-100 \mathrm{~m}$. They are similar to the zone N3 faunas of Skærumhede I (Knudsen and Lykke-Andersen, 1982), and like this zone they are referred to the Eemian Interglacial.

The presence of significant amounts of Elphidium excavatum and Cassidulina reniforme in the lowermost sample $(216.60 \mathrm{~m})$ of zone N3 in Stenhave suggests, that a transition from a colder period may have occurred at this level. This was also noted in the Apholm (7.131b) boring (Knudsen, 1984) from an undisturbed core sample rather than a cutting sample as in the present borehole.

The dominance of Elphidium excavatum in the sample at $190 \mathrm{~m}$, which is in the middle of zone $\mathrm{N} 3$, is difficult to explain. A similar succession is seen in a few other borings from the area (e.g. Ålbæk 6.30 and Jerup W. 7.579). It may indicate fluctuating marine-climatic conditions through the Eemian. Considering however, that none of these anomalous faunas have been found in core samples (e.g. Knudsen, 1984), it is more likely to have resulted from down-core contamination.

In the two clay samples from 170 and $160 \mathrm{~m}$ depth both Elphidium excavatum and Cassidulina reniforme increase in importance, whilst Bulimina marginata and Cassidulina laevigata decrease. A characteristic of these faunas is the presence of small Elphidium species, such as $E l$ phidium margaritaceum, E. gerthi and E. albiumbilicatum. The faunas indicate shallower water and cooler conditions than in zone N3. They correspond to the zone N2 faunas of the Skærumhede I boring (Knudsen and Lykke-Andersen,
1982). This zone was referred to the Early Weichselian by Knudsen (1984).

The interval from $150 \mathrm{~m}$ to $53 \mathrm{~m}$ depth is included in zone N1. The sediment in the lower part is clay and sandy clay, but above $123 \mathrm{~m}$ layers of sand and clay alternate and stones appear above $60 \mathrm{~m}$ depth. No samples exist from a stony layer at $98 \mathrm{~m}$ depth. Elphidium excavatum and Cassidulina reniforme dominate this zone, reflecting mainly arctic conditions. This climatic indication is also supported by the accessory species (fig. 4). It is clear that the present zone corresponds to the Weichselian zone N1 of the Skærumhede I boring (Knudsen and Lykke-Andersen, 1982), but on the basis of the present material it is not possible to make a detailed correlation with the foraminiferal zonation of the Weichselian in the Skærumhede II boring (Konradi and Knudsen, 1974; Knudsen, 1976).

As mentioned above the faunal succession found in the Stenhave boring is typical of most of the investigated boreholes in the Frederikshavn area.

\section{Frederikshavn boring 7.602}

Boring 7.602 is located about $2 \mathrm{~km}$ east of Stenhave 7.614 and $8 \mathrm{~km}$ east of Skærumhede (figs. 2 and 3). The borehole site is $20.7 \mathrm{~m}$ a.s.1., and the boring was $200.2 \mathrm{~m}$ deep. The available material was mostly washed samples $(>0.1 \mathrm{~mm})$ from cuttings, but a few core samples were also present. All the faunas were anlysed, and the marine sequence from $60 \mathrm{~m}$ to $192 \mathrm{~m}$ depth was subsequently subdivided into six biozones (fig. 6).

The lower $2.5 \mathrm{~m}$ of boring 7.602 has been interpreted as a glaciofluvial gravel mixed with lumps of calcareous sandy till (as described in the files of the Geological Survey). Three samples from this deposit were analysed. The content of Quaternary foraminifera was very low, but the amount of pre-Quaternary specimens was high. There are only few reworked pre-Quaternary specimens in all the samples from the marine sequence above.

Zone $C R$, the Cassidulina reniforme zone, from 192 to $185 \mathrm{~m}$ depth, consists of clay and sandy clay. Three samples were assigned to this zone, viz. two unwashed core samples weighing $10 \mathrm{~g}$ each and one washed fraction $(>0.1 \mathrm{~mm})$ of 


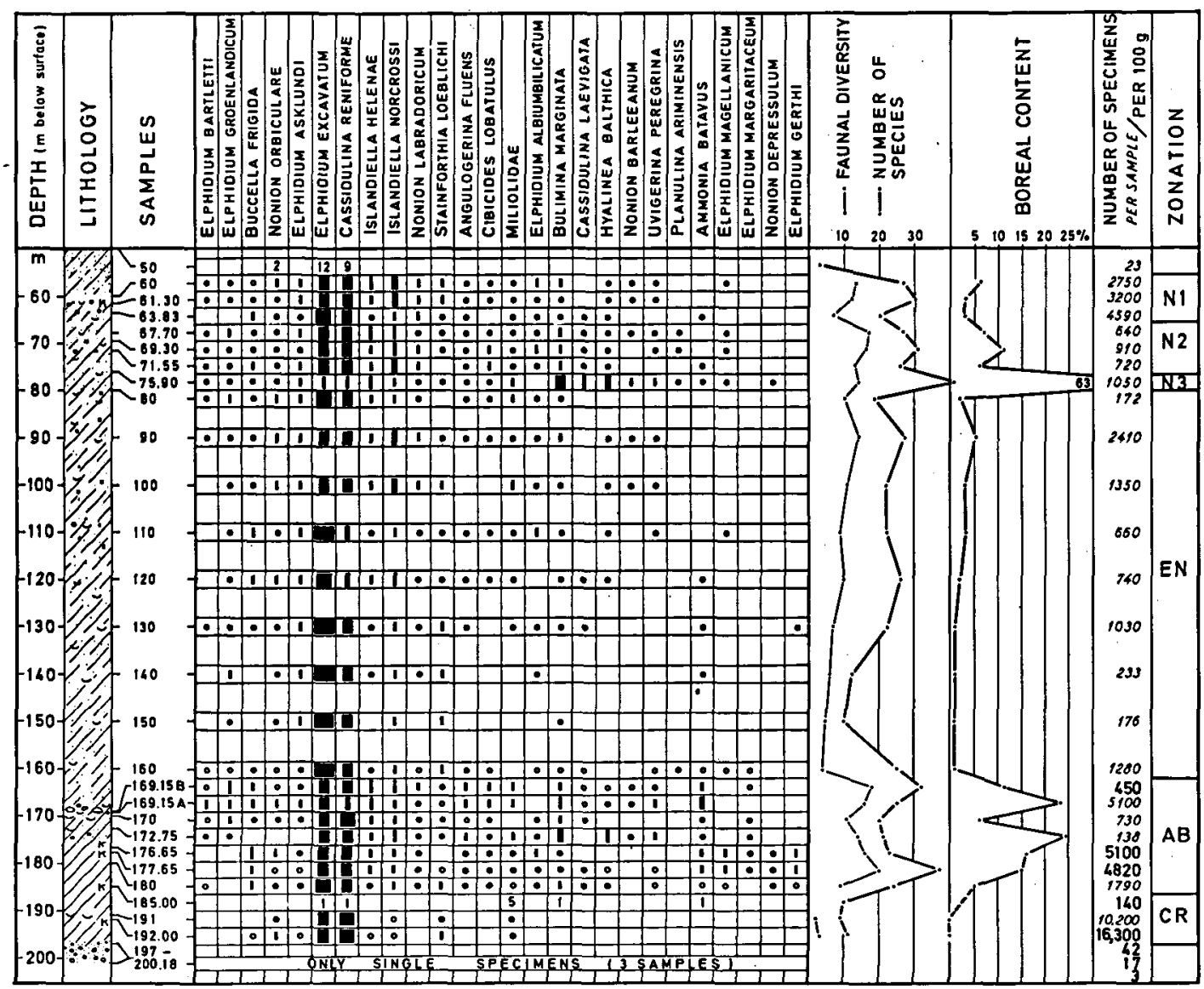

Fig. 6. Percentage distribution of selected foraminiferal species in Frederikshavn boring 7.602 (legend fig. 5). $\mathrm{K}=$ core sample. Numbers in italic indicate actual specimen numbers in previously washed samples (unknown weight). Ground level is $20.7 \mathrm{~m}$ above sealevel.

a cutting sample. The uppermost fauna $(185 \mathrm{~m})$ was poor, but the two others were very rich in foraminifera. A characteristic of these faunas is the high dominance of Cassidulina reniforme. Elphidium excavatum is also important, but only a few accessory species, such as Nonion orbiculare and Stainforthia loeblichi, occur. These faunas indicate high-arctic marine conditions, normal marine salinities and a water depth of at least $20 \mathrm{~m}$. Zone CR represents a glacial period.

Zone $A B$, the Ammonia batavus zone, covers the interval from $180 \mathrm{~m}$ to $169.15 \mathrm{~m}$ depth in the borehole. The sediment is clay and sandy clay in the lower part. At $170 \mathrm{~m}$ depth, and also in the interval from 169.15 to $169.65 \mathrm{~m}$ (samples 169.15 $A$ and $B$ ), it is mainly sand with pebbles and rounded stones. Seven samples were analysed from zone $A B$, two of these consisted of raw ma- terial of core samples (177.65 $\mathrm{m}$ and $176.65 \mathrm{~m})$, one sample (169.15 B) was an unwashed cutting sample, and the remaining four were washed fractions $(>0.1 \mathrm{~mm})$ of cuttings.

The foraminiferal faunas are dominated by $E l$ phidium excavatum and Cassidulina reniforme, although the boreal content remains characteristically high (fig. 6). The most frequent boreal species are Bulimina marginata and Ammonia batavus, and other common boreal indicators are Hyalinea balthica, Uvigerina peregrina, Cassidulina laevigata and Elphidium albiumbilicatum. Accessory arctic species, such as Buccella frigida, Islandiella helenae and Islandiella norcrossi, occur together with the boreal elements, and in the upper part of zone $\mathrm{AB}$ Elphidium bartletti and Elphidium groenlandicum are also present.

Zone AB would appear to possess a mixture of 
arctic and boreal species, but the faunal composition remains remarkably consistant throughout the zone, and as mentioned above two of the samples were core samples. Zone AB may therefore belong to an interstadial period, or perhaps even an interglacial.

Zone EN, the Elphidium excavatum-Islandiella norcrossi zone, covers the interval from $160 \mathrm{~m}$ to $80 \mathrm{~m}$ depth. The sediment is sandy clay with some pebbles in the upper part (from $110 \mathrm{~m}$ to 80 $\mathrm{m}$ depth). Nine washed fractions $(>0.1 \mathrm{~mm})$ of cutting samples were examined here. They contain arctic faunas with Elphidium excavatum and Cassidulina reniforme as the two dominant species. Islandiella norcrossi is especially common in the upper part of the zone. The EN faunas all indicate glacial conditions, but as the sampling interval was $10 \mathrm{~m}$, other biozones within this zone may have escaped attention.

One sample of sandy clay from $75.90 \mathrm{~m}$ depth in the borehole is referred to zone N3. The dominant species are the boreal Bulimina marginata and Hyalinea balthica, and other boreal indicators, such as Cassidulina laevigata, Nonion barleeanum and Uvigerina peregrina are also common. This faunal composition corresponds to the zone N3 faunas described above from Stenhave 7.614 and from Skærumhede I (Knudsen and Lykke-Andersen, 1982). The sample at $75.90 \mathrm{~m}$ was a washed fraction ( $>0.1 \mathrm{~mm})$ of a cutting, and therefore the fauna may contain some contaminants from the layers above. Nevertheless, the fauna is markedly different from those both above and below, and it certainly represents an interglacial period, presumably the Eemian.

The sediments from 71.55 to $67.70 \mathrm{~m}$ comprise clay and sandy clay with a rather high content of coarse sand and pebbles. The faunas are mainly arctic, but boreal species are also present, such as Bulimina marginata, Elphidium albiumbilicatum and Cassidulina laevigata. This sequence seems to correspond to zone N2 of the Skærumhede I boring. This interpretation is however, rather uncertain, because all the samples are washed cuttings, and the faunas are not much different from the zone N1 faunas above. Zone N2 is distinguished on the basis of its slightly higher boreal content and its lower number of specimens (fig. 6).

The samples from $63.83 \mathrm{~m}$ to $60 \mathrm{~m}$ depth are included in zone N1. The sediment is mainly sand, but there are a few pebbles in sample 61.30 $\mathbf{m}$, which is a core sample. The faunas are arctic in composition (fig. 6), and the unit is correlated with zone N1 of Stenhave 7.614, which is described above, and with zone N1 of Skærumhede I (Knudsen and Lykke-Andersen, 1982).

The marine sequence of $132 \mathrm{~m}$ thickness in Frederikshavn 7.602 seems to contain three glacial periods (Zones $\mathrm{CR}$, EN and N2-N1) separatied by two interglacials (zones $A B$ and $N 3$ ). If the present correlation of the interglacial zone $\mathrm{N} 3$ faunas is correct, at least a part of the underlying artic zone EN may correspond to zone N4 of Skærumhede I. As mentioned above, the climatic indication of the lower ameliorated period (zone $\mathrm{AB}$ ) is cooler than that of zone $\mathrm{N} 3$, and this zone may represent an interstadial rather than an interglacial period.

\section{The Cross-sections}

Six cross-sections (A-F; figs. 7-12) have been constructed across the Frederikshavn area based on correlation of the foraminiferal biozones identified in each borehole. The locations of these cross-sections are shown on figs. 2 and 3 . Skærumhede I and Apholm (7.131b) are here considered as key borings, as their zonation has been clearly established (see Knudsen and Lykke-Andersen, 1982; Knudsen, 1984). Moreover, Apholm is the only borehole, where core samples were available from all the zones.

\section{Cross-section A (fig. 7)}

This cross-section connects Skærumhede in the west to Apholm in the east (fig. 2). A more detailed comparison of Skærumhede I with Stenhave 7.614 and Frederikshavn 7.602 is given elsewhere in this paper (see above). The Eemian (zone N3) occurs at approximately the same depth (lower boundary at 155-164 m below sealevel (b.s.l.)) and is of similar thickness (about 40 m) at Skærumhede and Stenhave. It thins to less than $10 \mathrm{~m}$ in Frederikshavn 7.602, where it is found approximately $100 \mathrm{~m}$ shallower in the borehole. There it overlies three biozones, which were not present in any of the other boreholes. This may have been caused by considerable tectonic movements in the area during the Quater- 


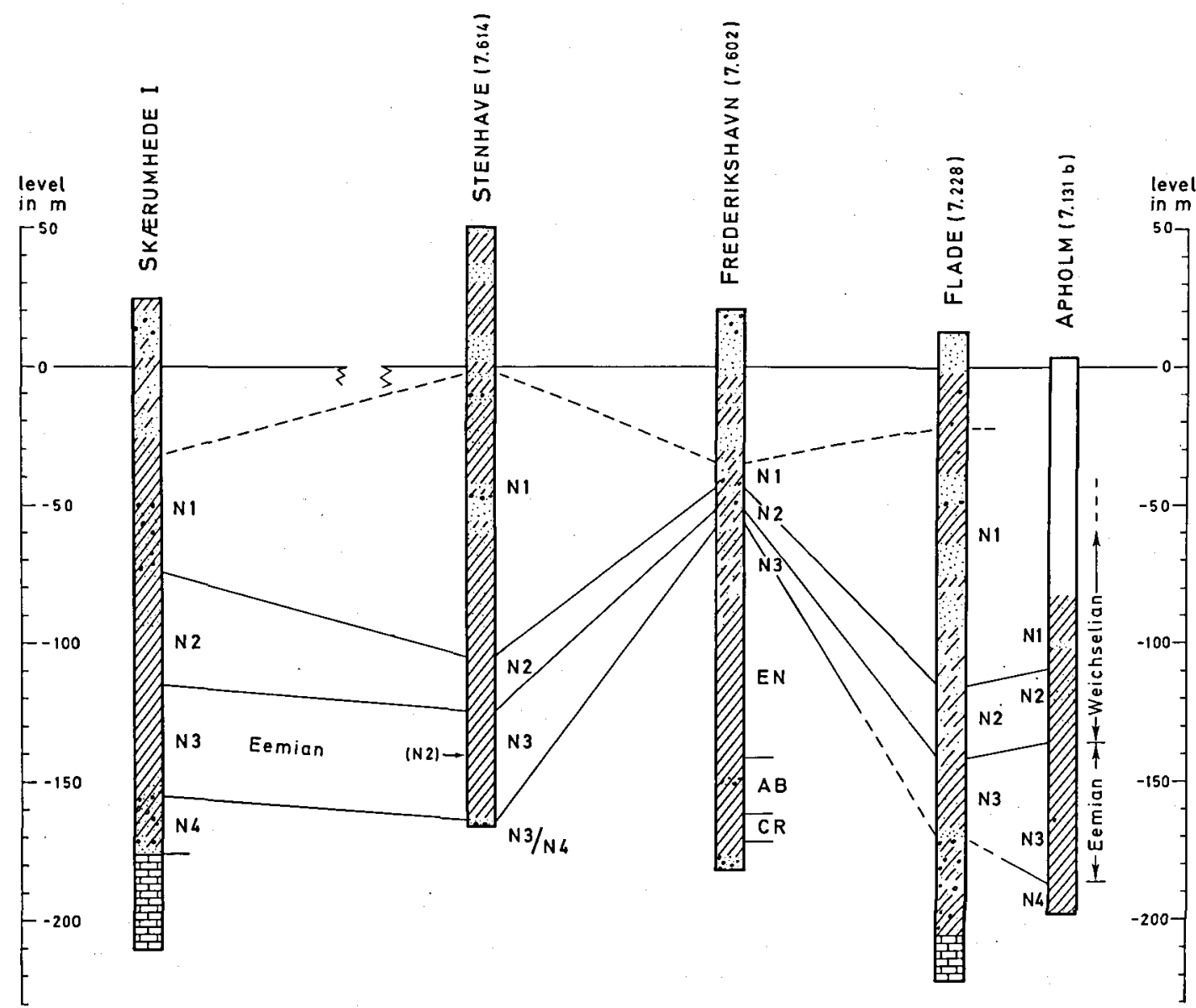

Fig. 7. Cross-correlation of biozones along section A. Location of borings is shown on fig. 2. Legend fig. 5 .

nary. Such an interpretation may not however, be justified owing to the aforementioned sampling problem in that borehole.

Further east at Flade 7.228 and Apholm $7.131 b$, zone N3 plunges to depth somewhat deeper than in Skærumhede $I$ and Stenhave 7.614. At Flade it is about $25 \mathrm{~m}$ thick, but its lower boundary has not been precisely defined. The lowermost sample at $183 \mathrm{~m}$ depth $(170.5 \mathrm{~m}$ b.s.l.) is still within zone N3. The original borelogs reported sand and sandy till overlying Upper Cretaceous Limestone at greater depths. Zone N3 is $50 \mathrm{~m}$ thick at Apholm and has well defined upper and lower boundaries. The underlying clays correspond to the arctic zone $\mathrm{N} 4$ in Skærumhede I and the transitional N3/N4 in Stenhave 7.614 .

Zone N2 is thickest at Skærumhede $(40 \mathrm{~m})$.
This zone indicates the onset of increasingly cooler conditions after the Eemian Interglacial. It would appear to thin slightly in easterly direction to about $20 \mathrm{~m}$, and also to increase in depth. It is not very well defined in the Frederikshavn 7.602 boring, where it again occurs at a much higher level.

The upper boundary of the arctic to boreal-arctic zone N1 is not very clearly defined based on the present material. A more detailed discussion of this boundary is therefore omitted.

Cross-section B (fig. 8)

This cross-section was drawn at approximately right angles to cross-section $\mathrm{A}$, from Skagen in the north to Hørby in the south (fig. 2).

Very little information can be gleaned from the 


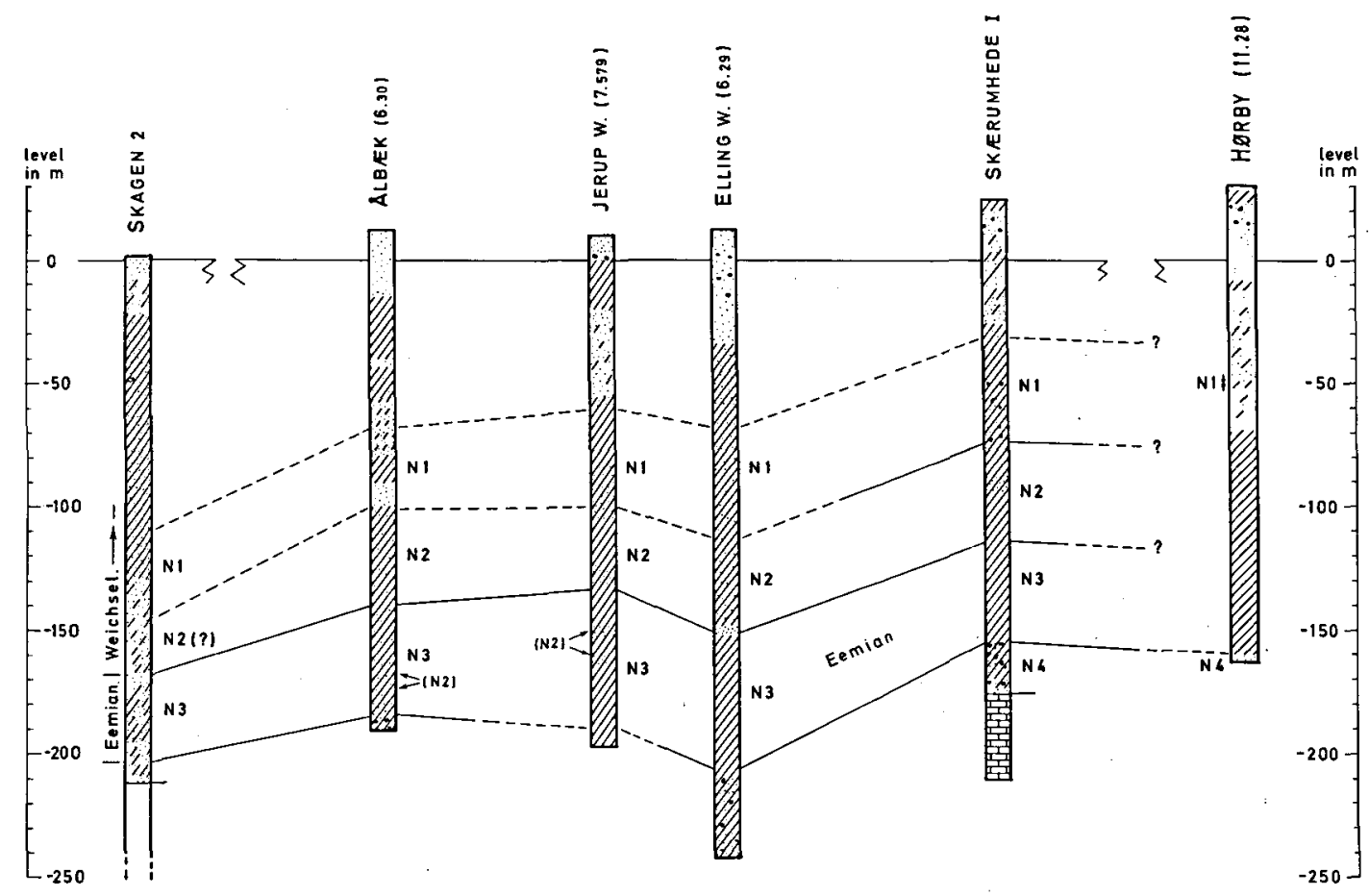

Fig. 8. Cross-correlation of biozones along section B. Location of borings is shown on fig. 2. Legend fig. 5.

Hørby (11.28) boring, as much of it was not sampled. Zone N4 faunas were nonetheless present at the base of the borehole. These were directly comparable with those observed at approximately the same level in Skærumhede I (Knudsen and Lykke-Andersen, 1982). The overlying clay sequence probably belongs to zones N3 and $\mathrm{N} 2$ as a few samples from around $50 \mathrm{~m}$ b.s.l. clearly belonged to zone N1.

The Eemian zone N3 is very distinctly defined north of Skærumhede I. A few mixed faunas were however, identified in two of the boreholes (fig. 8). This mixing has more than likely resulted from contamination during sampling, a problem which was observed by Arne Buch of the Geological Survey (pers.comm.). The lowermost boundary of N3 drops 30 to $50 \mathrm{~m}$ below the level observed at Skærumhede I. It ranges from 35 to $55 \mathrm{~m}$ in thickness, thinning out a little at Skagen. The faunas are directly comparable in all the boreholes except Skagen, where Bolivina cf. robusta is much more important. This could possibly suggest deeper water at the latter site during the Eemian. $B$. cf. robusta is a common species at present in the outer Oslofjord, at depths of greater than $100 \mathrm{~m}$ (Risdal, 1964) and in the Skagerrak (Höglund, 1947; Kihle, 1971). According to Thiede et al. (1981) and van Weering and Qvale (1983) its distribution may be controlled by the availability of well oxygenated waters at salinities of about $33-35 \%$. This species was not found in large numbers in zone N3 south of Skagen.

The arctic zone N4 was not observed underlying the Eemian in any of the boreholes north of Skærumhede in this cross-section. In the Jerup W. (7.579) borehole the deepest sample (190 m b.s.l.) contained a zone N3 fauna, and the underlying clays may also belong in zone N3. The lowermost $35 \mathrm{~m}$ of the Elling W. (6.29) boring penetrated non-marine sandy clay and clayey sand with pebbles and fragments of limestone. The original files of the Geological Survey record these as glaciofluvial deposits. In Ålbæk (6.30) the lowermost non-marine clay, containing sand and pebbles, was originnally interpreted as a clayey till (Geological Survey files). Finally, at Skagen 2 an non-marine sandy clay was also found at the base of the Quaternary sequence.

The Weichselian zones N2 and N1, which lie 


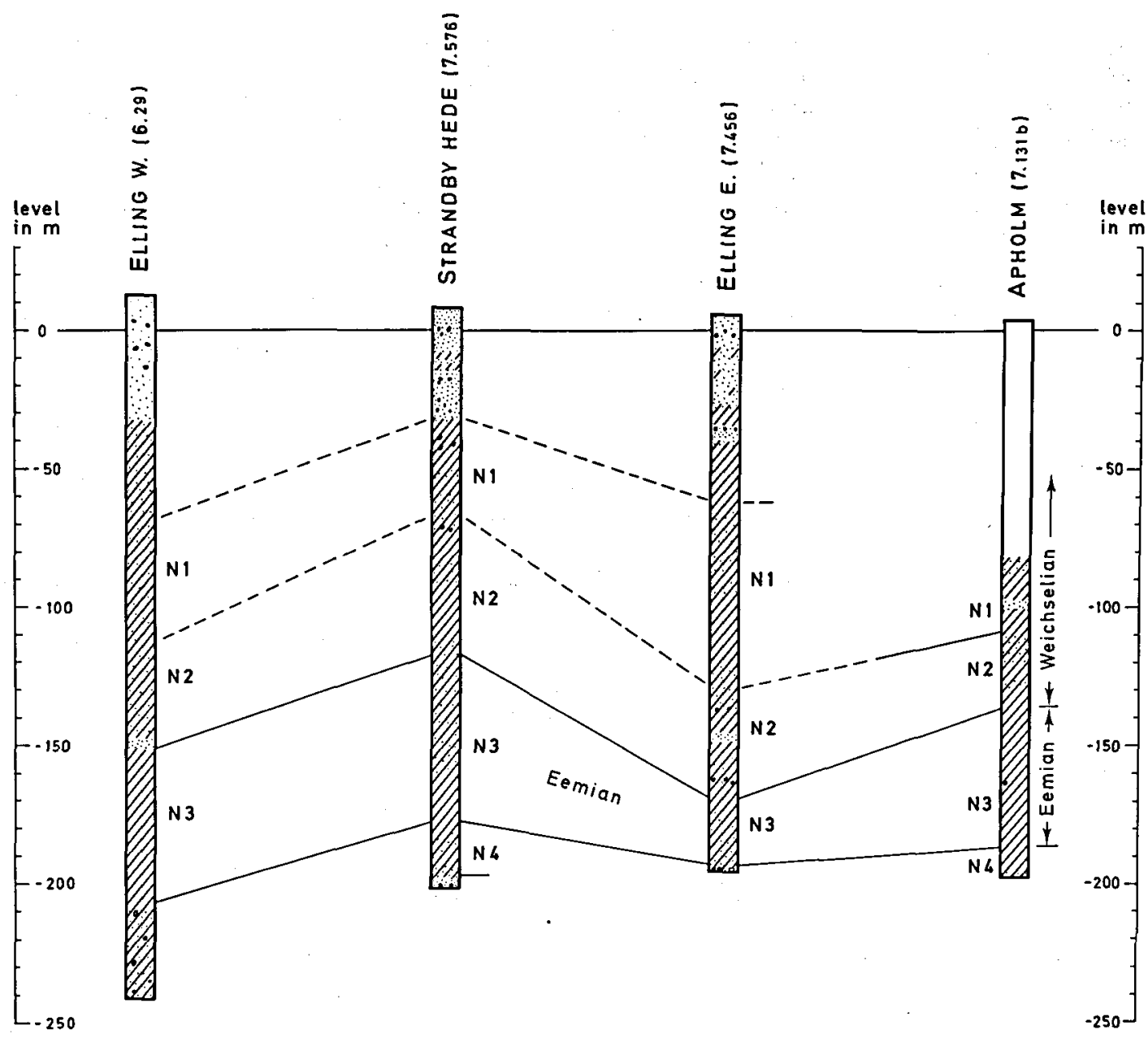

Fig. 9. Cross-correlation of biozones along section C. Location of borings is shown on fig. 2. Legend fig. 5 .

on top of zone $\mathrm{N} 3$, are seen plunge northwards in a similar fashion to the underlying deposits (fig. 8). It should however, be mentioned that the Quaternary sequence of the Skagen 2 boring is rather difficult to interpret in any detail. The borehole was put down without the use of an outer well casing, so that down-hole contamination is considerable. It seems that the Holocene sequence at this site may be up to $100 \mathrm{~m}$ in thickness. The first arctic faunas were recorded at 110 $\mathrm{m}$ b.s.l: (zone N1). The introduction of boreal species below $150 \mathrm{~m}$ may attest to the end of zone $\mathrm{N} 2$, while between 168 and 206 warm, deep-water faunas are present, which clearly belong to zone N3.
Cross-section C (fig. 9)

This cross-section has been alligned in a northwest-southeast direction between Elling W. (6.29) and Apholm (7.131b) (fig. 2).

Zone N3 is well defined in all the boreholes, attaining a maximum thickness of $60 \mathrm{~m}$ at Strandby Hede (7.576). It thins to $25 \mathrm{~m}$ at Elling $E$ (7.456). Its lowermost boundary ranges from about $200 \mathrm{~m}$ b.s.l. at Elling W. to $180 \mathrm{~m}$ at Strandby Hede.

The underlying arctic zone N4, described above in the Apholm boring, is also found at Strandby Hede, where it overlies non-marine sands and gravels. It was not found at either El- 
ling W. (see under cross-section B) or Elling E. The latter borehole bottomed at a non-marine stony sand, which was interpreted as a till in the original files.

The Weichselian N2 is only clearly defined at Apholm. Zone N1 is indistinct in all these boreholes (fig. 9).

\section{Cross-section D (fig. 10)}

This includes only the two boreholes investigated close to Jerup (fig. 2). The zonation of Jerup W. (7.579) is detailed above (see discussion of crosssection A). It includes zone N3 through to N1. The Jerup E. (7.481) boring was a little more than $230 \mathrm{~m}$ in depth but surprisingly did not possess a zone $\mathrm{N} 3$ fauna at any level. This zone may never have been deposited at this site at all. Alternatively it may subsequently have been re-

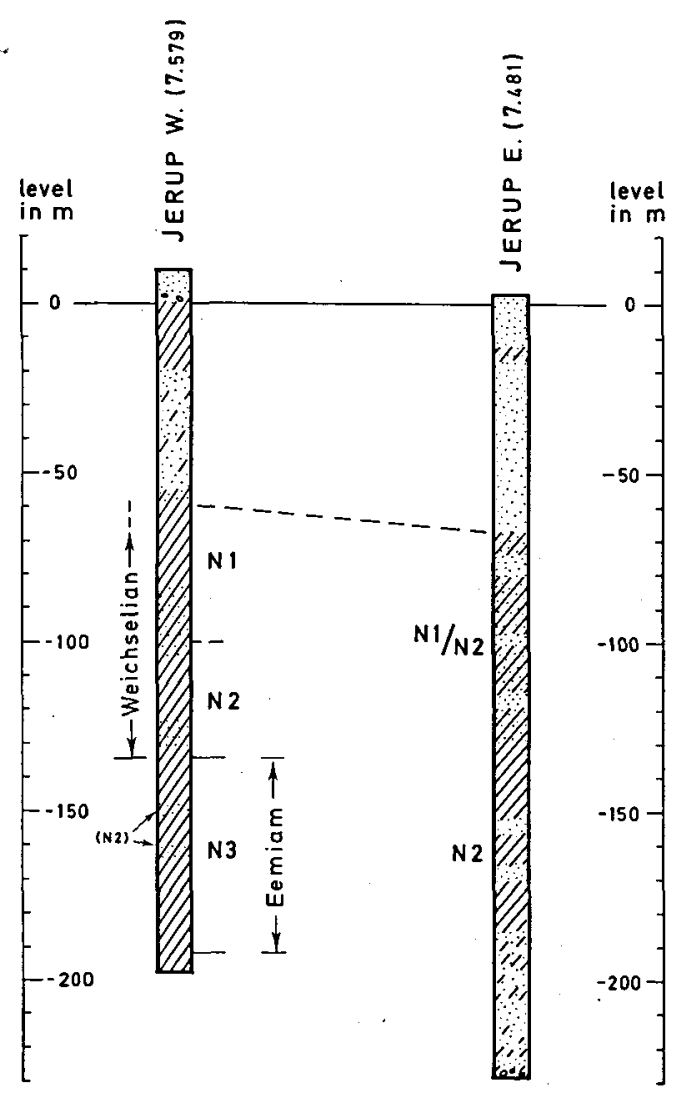

Fig. 10. Cross-correlation of biozones along section D. Location of borings is shown on fig. 2 . Legend fig. 5 . moved by erosion. The faunas present in the Jerup $\mathrm{E}$. boring are all arctic or boreal-arctic in character and must consequently belong to zones $\mathrm{N} 2$ and N1. These overlie a gravel with stones and fragments of limestone and chert, a deposit which was originally described as a till (Geologic Survey files).

\section{Cross-section E (fig. 11)}

This section travers the town of Frederikshavn from Apholm (7.131b) in the north to Frederikshavn (7.555) in the south (fig. 3 ).

The Apholm and Flade borings are discussed in more detail above (see cross-section A). Zone N3 thins between Apholm and Flade and then maintain a fairly uniform thickness and depth. Frederikshavn (7.545) did not however, penetrate the Eemian completely. The lowermost sample of Frederikshavn (7.555), at $175 \mathrm{~m}$ b.s.l., contained a mixed N3/N4 fauna. This directly overlay a sandy clay, which possessed bryozoans and limestone fragments. Zone N2 is well defined at Apholm and Flade, but less so to the south underneath Frederikshavn.

\section{Cross-section F (fig. 12)}

This section cuts across Frederikshavn from Stenhave to the west of the town to Frederikshavn (7.180) in the harbour area (fig. 3).

Only Frederikshavn (7.180) has not previously been discussed in this paper. Here zone N3 attains $60 \mathrm{~m}$ in thickness and drops to $187 \mathrm{~m}$ b.s.l. It succeeds non-marine sediments comprising a mixture of sandy clay and clayey sand with limestone fragments. Zone N4 is consequently not present.

The unusual biostratigraphical zonation of the the Frederikshavn (7.602) boring is discussed above (see cross-section $\mathrm{A}$ ). The upper zones (N2 and N1) of the present cross-section were less distinctively defined and hence, difficult to correlate. Especially problematical is the upper $100 \mathrm{~m}$ of Frederikshavn (7.180), where zone N3, $\mathrm{N} 2$ and $\mathrm{N} 1$ faunas were repeated at least three times (fig. 12). This may however, have resulted from contamination during sampling. No importance can therefore, be attached to these faunal peculiarities. 


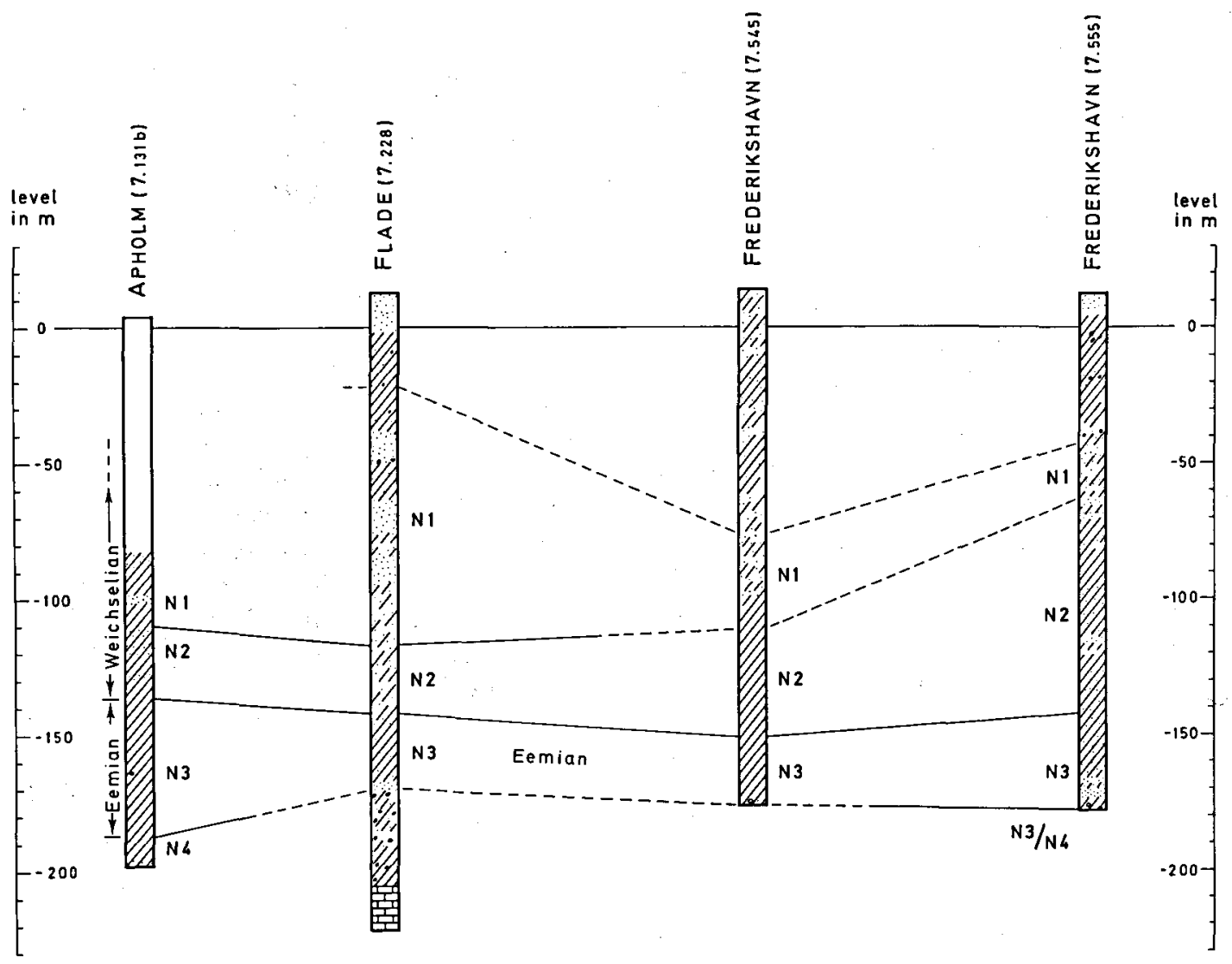

Fig. 11. Cross-correlation of biozones along section E. Location of borings is shown on fig. 3. Legend fig. 5.

\section{Foraminiferal list}

The following list includes only the foraminiferal species, which are mentioned in the text and on the range charts figs. 4 and 6 . Many other species were found in the material, but they usually occurred in insignificant quantitites in the faunas. For more detailed description of the foraminiferal faunas in marine Saalian, Eemian and Weichselian deposits of North Jutland the reader is referred to Lykke-Andersen (1971), Konradi and Knudsen (1974), Knudsen and Lykke-Andersen (1982) and Knudsen (1984).

Ammonia batavus (Hofker, 1951) Angulogerina fluens Todd, 1947

Bolivina cf. robusta Brady, 1884

Buccella frigida (Cushman, 1922)

Bulimina marginata d'Orbigny, 1826
Cassidulina laevigata d'Orbigny, 1826

Cassidulina reniforme Nørvang, 1945

Cibicides lobatulus (Walker and Jacob, 1798)

Elphidium albiumbilicatum (Weiss, 1954)

Elphidium asklundi Brotzen, 1943

Elphidium bartletti Cushman, 1933

Elphidium excavatum (Terquem, 1875)

Elphidium gerthi van Voorthuysen, 1957

Elphidium groenlandicum Cushman, 1933

Elphidium magellanicum Heron-Allen and Earland, 1932

Elphidium margaritaceum Cushman, 1930

Hyalinea balthica (Schroeter, 1783)

Islandiella helenae Feyling-Hanssen and Buzas, 1976

Islandiella norcrossi (Cushman, 1933)

Miliolinella subrotunda (Montagu, 1803)

Nonion barleeanum (Williamson, 1858)

Nonion depressulum (Walker and Jacob, 1798)

Nonion labradoricum (Dawson, 1960)

Nonion orbiculare (Brady, 1881)

Planulina ariminensis d'Orbigny, 1826

Pullenia osloensis Feyling-Hanssen, 1954

Quinqueloculina padana Perconig, 1954

Quinqueloculina seminulum (Linné, 1758)

Stainforthia loeblichi (Feyling-Hanssen, 1954)

Uvigerina peregrina Cushman, 1923 


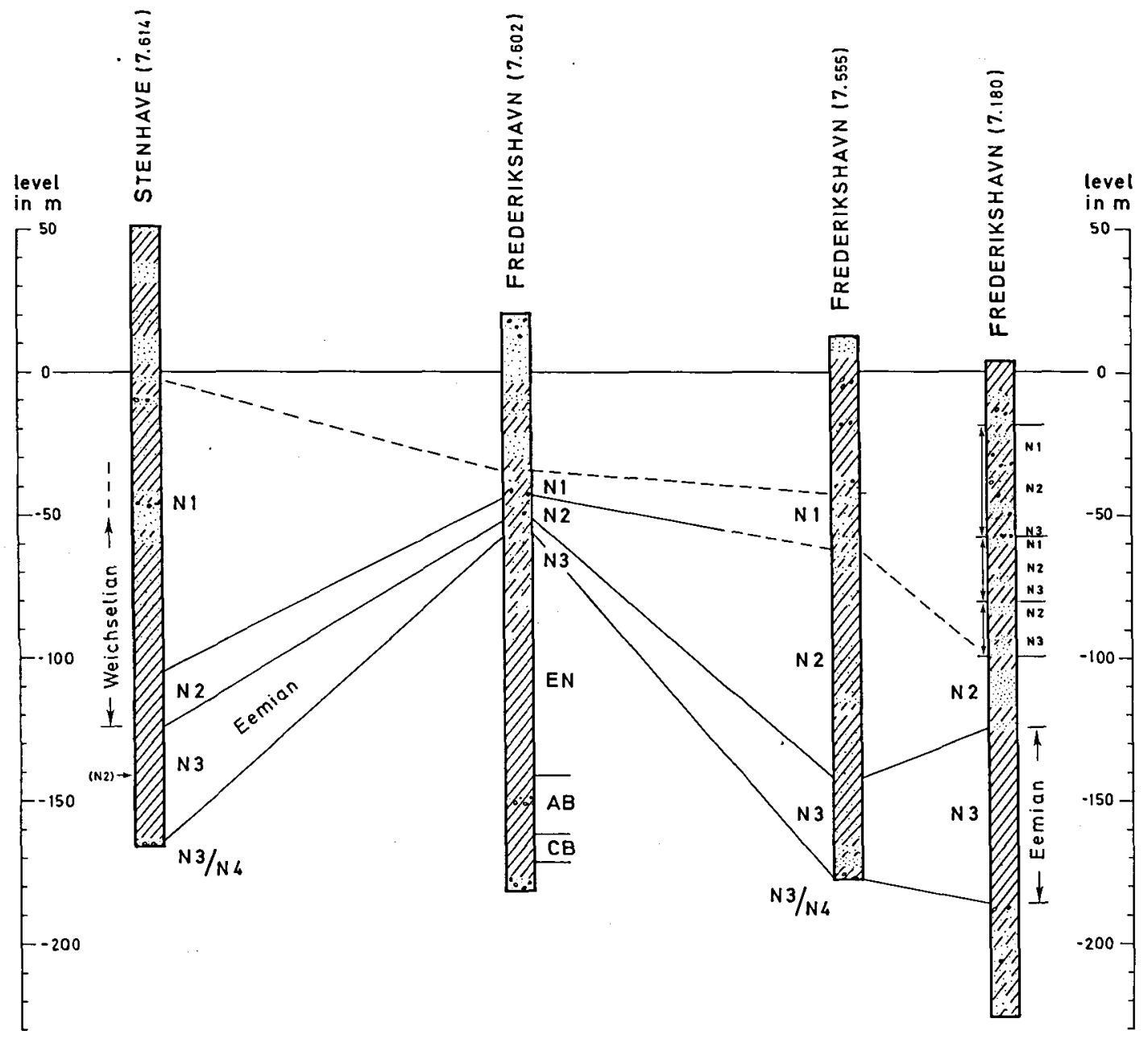

Fig. 12. Cross-correlation of biozones along section F. Location of borings is shown on fig. 3. Legend fig. 5 .

\section{Summary and conclusions}

The above discussion reveals that there is considerable uniformity in the marine Quaternary sequence to the north and west of Frederikshavn. Only two of the boreholes examined in the area produced anomalous results, viz. Frederikshavn (7.602) and Jerup E. (7.481).

The most well defined foraminiferal biozone across the whole area is zone N3. Its faunas indicate boreal to boreal-lusitanian conditions and water depths of around $100 \mathrm{~m}$. In addition the Skagen 2 faunas suggest deeper waters and higher salinities to the north. The N3 faunas of this borehole also contained som planktonic for- aminifera, as did part of the same zone at Apholm (Knudsen, 1984). Zone N3 ranges in average thickness from 25 to $60 \mathrm{~m}$, but is less than 10 $m$ thick in Frederikshavn (7.602) and totally absent from Jerup E. (7.481). Its lower boundary tends in general to drop in a northerly direction from $155 \mathrm{~m}$ b.s.l. in Skærumhede I to between 190 and $200 \mathrm{~m}$ b.s.l. in the north. Knudsen and Lykke-Andersen (1982) and Knudsen (1984) have referred zone N3 to the Eemian Interglacial, and Knudsen (1984) suggested a correlation with oxygen isotope stage 5e of Shackleton and Opdyke (1973).

An arctic marine zone N4 fauna is observed underlying the Eemian strata in seven boreholes 
between Hørby (11.28) in the south and Strandby Hede (7.576) in the north. To the north and west of the latter borehole and in four boreholes to the south, zone N3 lies directly on top of non-marine sediments. Zone N4 has previously been referred to the Saalian Glacial (Knudsen and Lykke-Andersen, 1982) and was correlated with oxygen isotope stage 6 by Knudsen (1984).

Zone N3 is superseded by the boreal-arctic zone $\mathrm{N} 2$ over the whole area. The lower boundary of this zone is always well defined, but its upper boundary is normally indistinct owing largely to the poor quality and unavailability of sufficient sample material. In the better quality boreholes (e.g. Skærumhede and Apholm) its thickness ranged from 20 to $40 \mathrm{~m}$. The zone $\mathrm{N} 2$ faunas presage the oncoming of a colder climate and a reduction in water depths. The zone has been referred to the beginning of the Weichselian and was tentitatively correlated with oxygen isotope stages 5a-d by Knudsen (1984).

Zone N1 was the most difficult zone to trace in detail across the entire region, owing again to the poor quality of much of the material. It is therefore impossible to obtain an overall picture of its thickness or level. It clearly overlies zone N2 and varies considerably in thickness over the whole area. This boreal-arctic to arctic zone has previously been referred to the Weichselian (Knudsen and Lykke-Andersen, 1982). It presumably comprises oxygen isotope stages 4 and 3 by Shackleton and Opdyke (1973).

Three biozones were present below zone N3 in the Frederikshavn (7.602) boring, which were not observed at any other locality. The upper part of the arctic zone EN just below N3 could however, correspond to zone $\mathrm{N} 4$, which has been referred to the Saalian. This would imply that zone $A B$, which represents a warm period, may either have been deposited during a Saalian Interstadial or perhaps, the Holsteinian Interglacial. The lowermost arctic zone CR would consequently either belong in the earlier part of the Saalian or in the Elsterian. It is notable that corresponding arctic and boreal zones were also found below a marine Eemian sequence in the Anholt boring (Lykke-Andersen, pers.com). Any further conclusions cannot be arrived at without more reliable sample material.

The overall difference of $30-40 \mathrm{~m}$ in the level of the Eemian zone N3 between southwest and the north and east, could be a real phenomenon. It could also however, be a product of Quaternary tectonic movements in the area - either regionally of locally. Local tectonic movements would for example explain both the absence of zone N3 at Jerup E. and the peculiarly complex biostratigraphy of Frederikshavn (7.602).

Acknowledgments. I am grateful to the Geological Survey of Denmark for placing material from the borings at my disposal, and my special thanks to Arne Buch for information about the boring techniques and the reliability of the samples. I want to thank Rolf W. Feyling-Hanssen and Anne-Lise Lykke-Andersen for valuable discussion during the present work and David N. Penney, University of Dublin, Ireland for improving the English of my text. My thanks also to Svend Meldgaard, who processed the samples, to Jette Gissel Nielsen, who made the drawings and to Lissi $\emptyset$ sterhaab Mogensen, who typed the manuscript.

\section{Dansk sammendrag}

Der er foretaget en foraminifer-stratigrafisk korrelation af Kvartære aflejringer i 16 boringer pả mellem 190 og $254 \mathrm{~m}$ dybde fra Frederikshavn området. Undersøgelsen viser, at der er en generel overensstemmelse i den marine lagserie over det meste af området. Kun $i$ to af boringerne er zonationen anderledes end det normale, nemlig i Frederikshavn (7.602) og Jerup E. (7.481).

Den mest veldefinerede zone $\mathrm{i}$ de undersøgte boringer er zone N3, der indeholder boreale til boreal-lusitanske faunaer fra vanddybder på op mod omkring $100 \mathrm{~m}$. Fauna-elementer $\mathrm{i}$ zone N3 fra Skagen 2 boringen tyder på endnu dybere vand og højere salinitet mod nord. Zone N3 varierer normalt i tykkelse fra 25 til $60 \mathrm{~m}$ i området, men er mindre end $10 \mathrm{~m}$ tykt i Frederikshavn (7.602) og forekommer slet ikke i Jerup E. (7.481) boringen. Generelt ligger den nedre grænse af zone N3 omkring 30-40 $\mathrm{m}$ dybere mod nord og nordøst end $\mathrm{i}$ sydvestlig retning. Zone N3 henføres til Eem (Knudsen og Lykke-Andersen 1972; Knudsen, 1984), og en korrelation med oxygen istotop enheden 5e (Shackleton og Opdyke, 1973) er foreslået af Knudsen (1984).

I syv af boringerne, fra Hørby (11.28) i syd til Strandby Hede (7.576) i nord, forekommer en arktisk marin zone N4 under Eem aflejringerne. I de øvrige boringer hviler zone N3 oftest direkte på non-marine Kvartære aflejringer. Zone N4 henføres til Sen Saale (Knudsen og Lykke-Andersen, 1982) og er korreleret med oxygen isotop enheden 6 af Knudsen (1984).

Zone N2 forekommer over zone N3 i hele det undersøgte område. Den nedre grænse er veldefineret, mens den øvre grænse oftest er utydelig på grund af prøvematerialets kvalitet. Zone N2 har normalt tykkelser på mellem 200 o $40 \mathrm{~m}$. Faunaerne viser en gradvis overgang til koldere forhold gennem hele zone N2. Ved overgangen fra N3 til N2 sker samtidig med klimaforandringen en pludselig andring til lavere vanddybde. Denne grænse korreleres med gransen mellem Eem og Weichsel, hvor en sankning af havniveauet på omkring $50 \mathrm{~m}$ er beskrevet. Zone $\mathrm{N} 2$ henføres således til den klimatiske overgangszone i tidlig Weichsel (Knudsen, 1984) svarende til oxygen isotop enhederne 5a-d.

Zone $\mathrm{N} 1$ er vanskelig at udskille helt entydigt på det foreliggende materiale, men det fremgår klart, at skiftende arktiske og boreal -arktiske faunaer forekommer over zone N2 i hele området. Zone N1 henføres til Weichsel (Knudsen og Lykke- 
Andersen, 1982), og omfatter formodentlig oxygen isotop enhederne $4 \operatorname{og} 3$.

I boringen Frederikshavn 7.602 forekommer endnu tre foraminifer -zoner under zone N3. Faunaerne i disse afspejler to arktiske perioder adskilt af en boreal til arktisk-boreal. Det er usikkert, om hele denne lagserie kan henføres til Saale (stadialer + interstadial), eller om zone $A B$ eventuelt repræsenterer en aldre interglacial tid (Holstein?). I en boring fra Anholt har Lykke-Andersen (pers.com.) fundet tilsvarende marine arktiske $o g$ boreale foraminifer -zoner under en marin aflejring fra Eem. Et langt bedre prøvemateriale er dog nødvendigt for at nå frem til en mere sikker tolkning af disse ældre marine zoner.

Den generelle niveauforskel på 30-40 m for Eem-aflejringerne (zone N3) fra sydvest mod nord og øst kan skyldes en oprindelig topografi i området. Det kan imidlertid også være et resultat af tektoniske bevægelser i Eem eller senere - enten regionalt eller lokalt. Lokale tektoniske forstyrrelser kunne for eksempel forklare de helt specielle biostratigrafiske forhold ito af boringerne fra området.

\section{References}

Bahnson, H., Petersen, K. S., Konradi, P. B. and Knudsen, K. L. 1974: Stratigraphy of Quaternary deposits in the Skarumhede II boring: lithology, molluscs and foraminifera. Danm. geol. Unders., Ärbog 1973, 27-62.

Feyling-Hanssen, R. W., Jørgensen, J. A., Knudsen, K. L. and Lykke-Andersen, A.-L. 1971: Late Quaternary Foraminifera from Vendsyssel, Denmark and Sandnes, Norway. Bull. geol. Soc. Denmark, 21 (2-3), 67-317.

Höglund, H. 1947: Foraminifera in The Gullmar Fjord and the Skagerak. Zool. Bidr. frän Uppsala, 26, 1-328.

Jessen, A., Milthers, V., Nordmann, V., Hartz, N. and Hesselbo, A. 1910: En boring gennem de kvartære Lag ved Skærumhede. Danm. geol. Unders., II Række, 25, 1-175.

Kihle, R. 1971: Foraminifera in five sediment cores in a profile across the Norwegian Channel south of Mandal. Norsk geol. Tidsskr., 51, 261-286.

Knudsen, K. L. 1976: Foraminifer faunas in Weichselian stadial and interstadial deposits of the Skærumhede boring, Jutland, Denmark. Maritime sediments, Spec. Publ. 1, BPaleoecology and Biostratigraphy, Halifax, 431-449.

Knudsen, K. L. 1984: Foraminiferal stratigraphy in a marine Eemian -Weichselian sequence at Apholm, North Jutland. Bull. geol. Soc. Denmark, 32, 169-180.

Knudsen, K. L. and Lykke-Andersen, A.-L. 1982: Foraminifera in Late Saalian, Eemian, Early and Middle Weichselian of the Skarumhede I boring. Bull. geol. Soc. Denmark, 30, 97-109.

Konradi, P. B. and Knudsen, K. L. 1974: Foraminifera in the Skærumhede II boring, 43-57. In: Bahnson, H., Petersen, K. S., Konradi, P. B. and Knudsen, K. L. 1974.

Lykke-Andersen, A.-L. 1971: Foraminifera from the Older Yoldia Clay in Hirtshals, 159-184. In: Feyling-Hanssen, R. W., Jørgensen, J. A., Knudsen, K. L. and Lykke-Andersen, A.-L. 1971.

Meldgaard, S. and Knudsen, K. L. 1979: Metoder til indsamling og oparbejdning af prover til foraminiferanalyser. Dansk Natur - Dansk Skole, Ärsskrift 1979, 48-57.

Risdal, D. 1964: Foraminiferfaunaenes relasjon til dybdeforholdene $i$ Oslofjorden, med en diskusjon av de senkvartære foraminifersoner. Norges Geol. Unders., 226, 1-142.

Shackleton, N. J. and Opdyke, W. D. 1973: Oxygen isotope and paleomagnetic stratigraphy of equatorial Pacific core V28-238: Oxygen isotope temperatures and ice volumes on a $10^{5}$ year and $10^{6}$ year scale. Quaternary Research, 3, 39-55.

Thiede, J., Qvale, G., Skarboe, O. and Strand, J. E. 1981: Benthonic foraminiferal distributions in a southern Norwegian fjord system: a re-evaluation of Oslo Fjord data. Spec. Publs int. Ass. Sediment., 5, 469-495.

Weering, T. C. E. van and Qvale, G. 1983: Recent sediments and foramiferal distribution in the Skagerrak, northeastern North Sea. Marine Geology, 52, 75-99. 